\title{
Articles
}

\section{United for Marriage: Dynamics of Elderly Couples}

\author{
Beatriz Porpino do Rosário Chacona , Janari da Silva Pedroso*a
}

[a] Federal University of Pará, Belém, Brazil.

\begin{abstract}
In the face of aging population and the fluidity of intimate relationships, this qualitative study aimed to understand the conjugal dynamics of elderly couples who have been together for more than 20 years. Reflections about the aging, the conjugality formation and the marriage transformations were made by the psychodynamic bias. The Mini-Exam of the Mental State was applied to five Brazilian couples aged from 60 to 83 years old, with an average marriage time of 41.6 years, who were at last interviewed. Such interviews were guided by a semidirected script with identifying data and five questions previously elaborated according to the research objective. This content was analyzed and their results were thematized showing that couples perceive marriage as a union requiring commitment and sharing of life projects. It was concluded that even amidst a hedonist society, the elderly are not yet thoughtful of individuality, because love for them has a connotation other than a sum of pleasurable moments.
\end{abstract}

Keywords: family processes, household living arrangements, intergenerational, intimate relationships, life course

Interpersona, 2020, Vol. 14(1), 1-14, https://doi.org/10.5964/ijpr.v14i1.3917

Received: 2019-04-29. Accepted: 2020-04-15. Published (VoR): 2020-07-02.

*Corresponding author at: Programa de Pós-Graduação em Psicologia and Programa de Pós-Graduação em Teoria e Pesquisa do Comportamento,

Federal University of Pará, Rua Augusto Corrêa, 01, Belém, PA/Brazil, 66075-110. E-mail: pedrosoufpa@gmail.com

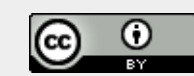

This is an open access article distributed under the terms of the Creative Commons Attribution 4.0 International License, CC BY 4.0 (https://creativecommons.org/licenses/by/4.0/), which permits unrestricted use, distribution, and reproduction in any medium, provided the original work is properly cited.

The marital relationship has been pointed out as a predominant factor to the families' health and life quality, particularly when it comes to the parental relationships and during the years of maturity and old age. However, it should be noted that not all long-term marriages are configured as a protection factor or are satisfactory to the spouses (Dessen \& Braz, 2000). This paper then discusses the marital dynamics of elderly couples and aims to understand their underlying subjective motives, thus identifying the factors that hold them together for over 20 years and the intergenerational patterns in loving choice.

The decision about the study's age group is justified not only because of all changes that happen to a relationship that is several years long, but also because of the elderly growth scenario worldwide and the intense social transformation related to marriage, which lasted longer in the past than it does now. In order to understand how those who have been together for decades experience conjugality is of fundamental importance for Psychology, especially regarding their physical and mental health, but only a few researches discuss the marriage lived by those who are over 60 years old (Alves-Silva, Scorsolini-Comin, \& Santos, 2017).

Among the various changes caused by aging, the experience of intimacy and affective relationships is highlighted by Pereira, Ponte, and Costa (2018), with peculiarities in elderly years. As the current generation of elders 
has been structured, in most cases, around the marriage, their identity and self-esteem are directly linked to the quality of the couple relationship. Newer generations, on the contrary, generally dismiss the idea of marriage as the center of happiness, usually seeking personal satisfaction in other areas.

In contemporary Western societies, the decision to join another person by a lasting bond can be a dilemma, because the personal satisfaction based on individualism and one's own professional achievement might outweigh the collectivity values. Conjugality is postponed so that people can invest in themselves, which leads to a conflict in order to reconcile romantic relationships towards individuality. In spite of this, it is possible to find couples who have been together for long and that have been through the various stages of the family life cycle without any concrete rupture (Alves-Silva et al., 2017).

In a study with thirty married people from 60 to 81 years old, Strey et al. (1999) noticed that the identity establishment for the elderly was influenced by marriage, this being relevant for the maintenance of individual dignity during the aging process. In the study, it was possible to see that, during the problems and conflicts of the couple, one of the factors keeping them in balance was that of friendship, which is opposed to the genitality when it comes to sex. Even if there are sexual difficulties in elderly couples, these are diminished by partnering in daily life a companionship trailed to the reasons that led them to get married. Although, in the sample, everyone had civil marriage certificates, they said that more importantly the relationship mattered in itself and not in the presence of a registry that guaranteed their relationship (Strey et al., 1999).

Alves-Silva et al. (2017) find that it a long-lasting relationship can be rewarding for the couple if they know how to respect individual differences and negotiate satisfactory ways to solve conflicts that arise. Maintaining marital harmony favors the personal maturity of the partners, but the way each perceives the marriage may be different and that perception may even be inconsistent between the spouses. After all, marriage is constantly transformed and needs to be reviewed in their goals and expectations.

As we propose to study the couples' dynamics, it is necessary to understand an important concept: conjugality. This term commonly designates the relationship built by the couple with the marriage, which differs from any other type of relationship established by the subjects. In the psychoanalytic knowledge of romantic relationships, conjugality is defined by the union of two subjects that carry a previous family history, which together weave an "identifying thread", then producing a common identity (Féres-Carneiro \& Ziviani, 2009).

In this sense, Féres-Carneiro and Ziviani (2009) state that all the magic and complexity of being a couple lies in the fact that it involves two individuals and, therefore, two different world perceptions, distinct desires, unique identities, singular life stories and life projects. All of which, when inserted into a relationship of affection and love, builds up a story for both, a common desire or will and, as a result, an identity that belongs to the conjugality. Such a construction depends on the bond of the couple, for which formation it is necessary a psychic availability towards the differences.

Also Eiguer (2008) holds that the bond of intersubjective character involves a degree of correspondence between the partners whose subconscious influence each other. A bond thus defined combines three psyches: those of both subjects and that of the relationship, without any overlap. The joint, in this case, is not of two persons, but of two subconscious subjects that aim to satisfy their desires through each other. 
Marriage thus fits this kind of choice strongly influenced by conscious and unconscious factors, as it is not something exclusive to the groom and bride but also under a strong influence from their original families who convey a complete system of myths and beliefs that are the cornerstone to structure a new couple. Conscious and unconscious factors, introjection of parental models, learned and repeated behavioral patterns and the accumulation of experiences from the original family are aspects that do not depend on the subject's will and propel their love life in different ways (Quissini \& Coelho, 2014).

Almeida and Romagnoli (2017) consider this unconscious dynamic of the couple, which keeps them united and precedes them, individually, as the continent factor to the inherited elements from generational transmission, i.e., as a form of preparation. Nonetheless, these same elements can also foment marital conflicts, such being aspects that studies about marital life linked to the intergenerationality cannot forget. There is no denying that the marital choices of a couple's children are influenced by the model that they have inherited from those who were also influenced by references of their predecessors. In this sense, the couple, both conjugal and parental, ends up being a receiver and transmitter of beliefs, emotions and values that permeate generations and lead to the perpetuation of the family (Féres-Carneiro \& Ziviani, 2009).

According to Féres-Carneiro and Ziviani (2009), beyond the influence of the parental model, the current marriage construction in the West is strongly influenced by individualism. The ideals crossing the marital bond put emphasis on the self-satisfaction and autonomy of each partner, which decreases the dependency relationship between them. However, the couple constitution emerges from a common interaction space, so it must develop a spousal identity. In this sense, the spouses face at all times a duality named by the author as "the difficult coexistence of individuality with conjugality" in one of his studies from 1998. While the couple need to live their conjugality, it's also socially induced to be autonomous and to seek their personal and professional growth, satisfying their individual desires.

The Western way to build relationships today causes the marriage to be maintained only as long as it is satisfying to both parties, so upon request by one of the spouses, the union comes to an end (Giddens, 1992). According to the Brazilian Institute of Geography and Statistics in 2014, the marriage rate was of 13\% per one thousand inhabitants who were 15 years or older in the 1970s. In the following decades, the rate declined to around $11 \%$ in the $1980 \mathrm{~s}, 7.96 \%$ in the 1990 s and then $7 \%$ at the beginning of the millennium. As data show, every year the marriage registrations decrease and the number of divorces grows.

In fact, from 1984 to 1994 , the divorces number has nearly tripled: from 30,847 to 94,126 . In 2004 , the total growth was of 130,527 , an increase of $38.7 \%$ when compared to the previous period. Ten years later, the growth was of $161.4 \%$. As a result, within 30 years (1984 to 2014), the length of marriage decreased from 19 to 15 years (Brasil, 2015). Based on Wagner and Levandowski (2008), it can be said that, despite various changes and ruptures on the ways to constitute a family, the cores that can keep clear limits among the members and support a hierarchy that preserves the functions of care, protection and affection towards children, are more likely to restructure successfully.

Finally, Almeida and Romagnoli (2017) suggest that it is necessary to reflect upon how the future marriages and marital ties can be in disregard of a common life project, in addition to revealing the difficulties amidst the marital dynamics of living with the otherness composed by subjects with unique stories. Therefore, from this context of ephemeral relationships, hyper valorization of satisfaction and pleasure, an education aimed 
at individualism, as well as marriages by love and with love, that this proposal to understand how marital dynamics of the old couples is born.

\section{Method}

\section{Participants}

Five elderly couples living in the Belém city (Brazil) were selected as a convenience sample. In order to participate in the survey, all subjects should be 65 years or older; to be lucid, conscious and with spatiotemporal orientation; to sign an informed consent term and to have been for at least 20 years in the same and only marital union. Exclusions criteria were to not meet at least one of the inclusion criteria and not to reach the minimum score on the Mini-Mental State Examination (MMSE). This minimum score was 20 points for illiterate participants and 24 for those with any schooling. Except for the participant Ellen (fictional names), who has had a diagnosis of postpartum psychotic depression, which did not hinder her spatio-temporal awareness, all the others were also lucid and able to participate, as shown by the Mini Mental Examination (MMSE) in Table 1, describing the participants.

Table 1

Characterization of the Participants

\begin{tabular}{|c|c|c|c|c|c|c|}
\hline Couple & Name & Age & MMSE & Education Level & Children & Marriage (years) \\
\hline \multirow[t]{2}{*}{1} & Kelly & 68 & 26 & High School & 3 & 44 \\
\hline & Edson & 75 & 27 & High School & & \\
\hline \multirow[t]{2}{*}{2} & Ellen & 65 & 25 & University & 1 & 36 \\
\hline & Isaac & 70 & 28 & University & & \\
\hline \multirow[t]{2}{*}{3} & Claire & 60 & 26 & High School & 2 & 36 \\
\hline & Paul & 67 & 26 & High School & & \\
\hline \multirow[t]{2}{*}{4} & Mary & 76 & 24 & University & 6 & 50 \\
\hline & Harry & 83 & 25 & University & & \\
\hline \multirow[t]{2}{*}{5} & Liz & 63 & 26 & Basic School & 4 & 42 \\
\hline & Arthur & 68 & 25 & High School & & \\
\hline
\end{tabular}

Note. MMSE $=$ Mini Mental State.

In addition to these data, all couples were Catholic and were already grandparents.

\section{Research Location}

The research was conducted in reserved rooms at the participant's residences.

\section{Instruments}

The Mini Mental State Examination (MMSE) proposed by Folstein, Folstein, and McHugh (1975), validated in Brazil in 1994, has been applied to assess cognitive function. Its seven categories are: spatial orientation, 
temporal orientation, attention, short-term memory and calculation, evocation, language and constructional apraxia (to copy a drawing).

A semi-directed interview was also used, consisting of two parts: the first about self-identification and the second with the following five themed questions: "What is marriage for you?", "What reasons have led you to marry him/her?", “Do you remember what your parents' relationship was like?", "Do you think yours is alike?", "Can you tell me which factors keep you together until today?", "What has changed from the beginning of marriage to now?". All questions thus being about aging and conjugality.

\section{Procedure}

The research was approved by the Research Ethics committee (CAAE Process number 64629716.8.00000.0017). Data collection has taken place in a single encounter per couple, starting from the presentation of the research, as well as its goals, and then proceeding to their acceptance to participate. At first, they were subjected to the Mini Mental State examination and then to the semi-directed interview, which was applied individually to spouses. The interview time ranged from one hour to a maximum two and a half hours, depending on each participant. The transcripts were made in literal form, so the lines quoted by the research are reliable to the interviews.

\section{Data Analysis}

The interviews data were submitted to the Content Analysis technique (Bardin, 2007), which holds on to the senses and meanings of messages transmitted by the interviewees. According to Bardin (2007), the most relevant in this analysis is to understand the collected data by analysis categories, which group messages with similar meanings and senses and therefore facilitate the interweaving of the results with the base theories of the study.

The analytic categories that were chosen after these data transcription were called: Marriage meanings; Family building; Religion; Faith; Parental models; Education; Values; Conflict resolution; Friendship; Feeling; Behavior change; Relationship with in-laws and the Couple's description. Later, the intermediate categories have been grouped, generating the four final categories: Couple's understanding about marriage; Partner choice and the relatives' influence; Conjugality in the elderly years and the Maintenance of the marriage.

\section{Results and Discussion}

\section{Couple's Understanding About Marriage}

Marriage as an institution undergoes several transformations, and so do the perceptions about it from time to time, for its design can be influenced by culture, by the socio-demographics context of the couples, by their family and social values and other determinants. Generally, for couples, marriage is linked to the notion of union, in which two people intertwine their lives from the affection that they nourish for each other. In addition, one of the common goals for the couple in opting for a marriage is the family constitution. The participants usually understand their marriage as it follows: 
Marriage is union, partnership, friendship, commitment, loyalty, love, reciprocity and all together will take us to the conjugal harmony. (Edson, interview).

Look, I think marriage is a real union (...). If the individual gets together with a person, they want to thrive, constitute family and give a normal sequence to life (Isaac, interview).

Marriage to me is a bond of love, life together, life in common. (Ellen, interview). Marriage is the union of two people aimed at forming a family and staying together, loving each other for... The true love, not passion, love indeed. (Mary, interview).

According to Andolfi, Angelo, and Saccu (1990), the simplest definition of a marriage is that it is configured as a model of intimacy experienced in adulthood, i.e., it is a kind of union between two persons with substantial culture differences between their original families. Thus it can be observed the idea of marriage as the basis for the relationship, the union of life and stories, that are intertwined and originate some common goals.

The marriage comes down to the union of people who love each other, so one might think that from the moment that there is no love anymore, there would be no marriage, and so it would be ended. Typically, this happens to relationships in Western contemporary society, where most of the time, marriage is only maintained if there is mutual love and it meets the emotional needs of both partners (Bauman, 2015).

For those elderly people, the concept of marriage is strongly coupled to the idea of "until death do us part". In the speech of Isaac's marriage, in addition to forming a family, it is a way to "give a normal sequence to life". This excerpt emphasizes that in his conception there is a family life cycle (Carter \& McGoldrick, 1995) to be fulfilled, that is, it is necessary to date, get engaged, marry, have children, see the kids grow up, experience the exit of the children out of their house, have grandchildren and enjoy the elderly years next to the spouse.

In addition, some excerpts denote that the couple must share a mutual commitment in order to consolidate their marriage, uniting their ideas of goals and accomplishments to be achieved, which can thus be called a shared vital project (Puget \& Berenstein, 1993). These common goals construction depends initially on the bond, which must be located within the same time-space. After that, it comes the professional and family plans, such as having kids and the necessary dyadic adjustment to raise them. The crisis possibly emerging from the non-achievement of these projects and the emotional creativity to create new plans are important and show how the couple structures itself.

However, even before the idea of a shared project, the conjugality does not have a permanent character. On the contrary, it is increasingly volatile, fluid, but it's still an easing factor to the identity construction of each partner, because there are unconscious needs to be met, like those about the feeling of existential emptiness, the desire to have an emotional support from someone, the sexual needs, the need of approval and even the possibility to feel free of the handcuffs placed by the original family (Féres-Carneiro \& Ziviani, 2009).

Therefore, with the results in hand it can be understood that the concept of marriage is not defined in a single word, because the plurality of responses implies different formulas about the marriage and the feelings involved. The data also show that the elderly have been influenced by the modern age which advocates the importance of affection, however this does not translate into fragility in the bonds as they are currently constituted, because all participants have been through various stages of the cycle: achievements and crises 
happened and they still remained together. In addition, the conjugality is unique and draws different stories, which reveals a lot about why they realize marriage differently from other couples.

\section{Partner's Choice and the Relatives' Influence}

The choice of a partner involves several aspects and the original family is among the most important ones. Considering that these couples are together, on average, for over 40 years and that at the beginning of their relationship the society was different from the current one, it was notable how the acceptance of the original family in relation to the chosen partner was relevant, i.e., how they were received by the family of the future spouse strengthened their bond and willingness to stay together. Also relevant to it were the similarities between the other's and the parental models, as well as the search in the spouse to fulfill affective needs that were unfulfilled by the original relatives.

The Family functions as an invisible set of rules governing familiar dynamics, being understood as a system that is structured through repeated patterns. Such standards are established when, how, and with whom members can relate (Eiguer, 2008; Minuchin \& Fishman, 2004). In this sense, the participants' speeches reveal the influence of the original relatives in the choice of their spouses and the construction of the conjugality of each, as it follows:

It's because he was a hard-working boy... My family also contributes a lot to this marriage because they liked him from the beginning and this led us until we got married. (Mary, interview).

I was always very well received from the start, I was accepted by her relatives, they thought I was a special guy. (Harry, interview).

I think it was her family's attachment, they welcomed me, then I liked her more and more and she liked me, until we got married. (Paul, interview).

I think it was like this... There was this attraction... How can I explain to you... For the person he is, for this humble person. He was like my father. I believe my relationship with Paul is similar to my parents'... I never heard my father offending my mother, my father was that man I put in my head that was how my husband had to be like. (Claire, interview).

In my house, because we are Arabs descendants, we are all a little cold-hearted... I lived with my sister-in-law and brother at the time it all happened (death of a boyfriend), and I talked to him, so first of all he was my friend, then he became my husband. (Kelly, interview).

To the Couple Mary and Harry, Mary's family in particular chose her future husband along with her. For her Family, he possessed important and necessary features for the relationship. This is clear when Mary says that her relationship is similar to that of her parents, which raises a reflection on the primary marital model influences. The same goes for Paul and Claire: in his case, she was chosen because he was welcomed into her family and Claire reveals that Paul was elected by attributes of his personality, his life history and the relationship he built with her family.

It is understood from the account of the four spouses the identification of the partner with the original family, especially when Claire says that one of the reasons that led her to marry Paul was that he was like her father and when Mary says she was in love with the father who had a great relationship with Harry, her husband 
nowadays. It is a process, mostly unconscious, to be in love with whom alludes to those performing the parental role.

Therefore, when one tends to repeat relational learned patterns, the subject is closely linked to the other by the Freudian process of identification (Freud, 2001). For Freudian psychoanalysis, the identification is understood as the first, and therefore oldest, expression of emotional attachment between two people. Thus, the first persons with whom any subject identifies themself are those who play the roles, either maternal or paternal, of care for them.

The participant Kelly reports that one of the reasons that led her to marry Edson was the fact that he dispensed affection and attention to her in a difficult time of her life, in which her family of origin, because of being culturally less affectionate, failed to supply her among her anguish, then from the friendship with Edson, it came love. In Kelly's case, the marital choice can be considered predominantly narcissistic, that is, focused to meet personal needs of complementarity (Freud, 2001).

From all of what has been exposed so far, then, one can understand that the family legacy is part of any individual's story. According to Kaës (2013), psychic transmission as a phenomenon occurs in all human beings, for it is organizes and structures the subjectivity. It could thus be inevitable that at birth or when leaving from a family one cannot do it without taking any psychic inheritance. In this way, the family is grouping and subjectivity oriented at the same time, because it organizes various psychic Locus, as in a group, and because it continuously reshapes the bonds and changes the psychic matter, allowing its members to develop, and thus become the source of unique psyches (Eiguer, 2008; Kaës, 2013).

\section{Conjugality in Elderly Years}

The conjugality in elderly years is different in fact through the time, so there is no surprise that the reality of the couple be transformed over the years. It is emphasized that at no time there was any indication that the elderly years and its implications were portrayed as a difficult phase given the consequences of aging. What was clear was that despite the changes experienced during the life cycle phases, couples were able to mature, to learn from mistakes and to overcome challenges. The feeling of union between them goes on, even though sexuality has been altered.

Lasting and satisfactory relationships, on the other hand, allow the marital system to become a refuge in relation to external stressors, as well as the matrix for contact with other social systems (Minuchin \& Fishman, 2004), which is quite relevant in the face of the growing longevity of the elder population. Carter and McGoldrick (1995) notice that, throughout the life cycle, the functioning and the structure of the family is transformed so that it fits appropriately to the changes of its members and the vicissitudes of life. This way, this category aims to understand how the relationship is set up after the couple has been together for so long. The next excerpts reveal what has changed in marriage over the years for the participants:

It changed for the better, oddly enough, because before he would leave on Fridays at $2 \mathrm{pm}$ and would only return the other day, now he does not go to the supermarket if I do not go with him. (Kelly, interview). 
I've grown a lot... The balance in the things that we do, the old escapes to have a beer with friends... so, gradually we become aware and do not do those anymore. I consider our relationship to be very good. (Edson, interview).

In relation to her, nothing! Only in relation to my behavior, stubborn, angry, my command is sometimes even dictatorial (...) The woman is at the heart of everything. What she says has a lot of wisdom. (Harry, interview).

It started to change after my thirties, I was a fool, I've been a board school student practically my whole life, I got out of boarding school when I was 14 and started dating him, so all that "yes", "no" life, "don't do anything wrong" ... I transferred that to him, I went on to obey him. Until I reached a point that I changed and went on to be his companion instead. (Mary, interview).

Look, I can't even figure out the difference from the first day to today, the affinity between us is so good that we cannot separate that time from today. (Isaac, interview).

Aah, a lot of things... I separated from my mother who was always around, I worked a lot when I came here, a lot of people think I was kind of disoriented because I was very lonely (she had post-birth psychosis), very shut and after my daughter was born that certain problems happened. (Ellen, interview).

Today I can tell you that I already look at Paul as if he were a friend, a friend who has no interest in the sexual matter, it is a union that I do not describe anymore as of a husband and wife. (Claire, interview).

Kelly's speech clearly reveals her husband's change in relation to the maturity he has achieved over the years. According to Fooken (2015), the maturity is part of human development and as in all other steps of life, elderly years also bring with it challenges of normative confrontations and typical behaviors for the age. For the author, the elderly years offer an opportune time for the subject to evaluate his life by revisiting the past and rearranging their experiences. Rabelo and Neri (2015) confirm this proposition by placing that, in the elderly years, changes in all areas of the subject's life causes them to review their life goals and family roles. So as the male elderly participants have matured, they've begun to give more importance to the family and no longer had the behaviors reported by their wives.

Harry did not refer to marriage changes. He said that his feelings for Mary remain the same after 50 years together and that nothing has changed. However, he perceives and recognizes his temperament, which certainly provided Mary's submission at the beginning. It's interesting to realize how much the positioning of Harry continues to annul Mary's voice within their relationship, even though years ago, according to her, her behavior had changed. This is noticeable in the contradiction of the couple's speeches: Harry says that his wife plays an important role in the marriage. However, this wisdom is cloaked by the resignation of Mary, who does not argue or yield so that a much idealized marital harmony may exist.

Isaac says there were no changes in the relationship during the coexistence years. Opposed to that, Ellen talks about striking events in her life after coming out of Minas Gerais to live in another state and to follow her husband, her separation from her mother, a job loss, the loneliness while her husband was working and the birth of their daughter were difficult situations for her to cope. Moments like these sure marked her and after experiencing them, she needed to adapt. These transformations combine with the family life cycle proposed by Carter and McGoldrick (1995), as when some stressors are present, there may be conflicts. 
For Claire, the greatest specificity in their current conjugality is based on the sexual matter. As inferred by Pereira, Ponte, and Costa (2018), the process of ageing changes the sexuality experience, which diminishes but does not end. This assertion contradicts the socially defended idea of non-sexualized elderly people. It is known that sexuality goes beyond the sexual act and can be lived in many ways, so it is not extinguished in the elderly. Affection, caresses, kisses among other romantic manifestations are part of sexuality. In addition to breaking barriers on the issue, it is important to realize the sexuality as one of the predictors to elderly's life quality.

In this context of linkage between the time passage and the conjugality, the marital dynamics show how couples build their love life and how they deal with the changes over time. The analysis of this category revealed that each couple has their own way of dealing with aging in the relationship and the most interesting thing was to realize the differences between the speeches of the partners that have revealed how much a lasting marriage needs space for otherness. This data is in line with that which was presented by Rios (2008), when he says that maintaining a relationship does not depend only on feelings, but rather on a willingness to let the other be who they are.

\section{Maintenance of the Marriage}

To maintain a healthy and lasting relationship from a psychological standpoint, without any doubt, depends on an intense and frequent affective investment. For couples, marriage depends on understanding and respecting individual differences, i.e.: it is important that during coexistence years the spouses can freely express their personalities, shaping whatever is necessary for the relationship. They reveal that, for this purpose, it is important to have fellowship and trust relations, while also emphasizing the importance of spirituality and the fulfilment of the spouses roles.

The analysis of marital structures of couples that have been together for more than 20 years must consider the changes that occurred during the relationship. It is a period of time when children, if they had any, probably have already left their homes and the couple's professional life, in most cases, has been interrupted by retirement, illnesses or simply due to aging. These facts do not prevent marriage from being a continuous source of well-being; instead, in elderly years there is more time to stay together and to review what has been accomplished, what losses and gains they have had and what they can give new meaning within the relationship (Norgren, Souza, Kaslow, Hammerschmidt, \& Sharlin, 2004).

In this context, the participants reported the following:

I don't think love is lost, it's a different experience. Today you marry young is one thing, in the middle of the way is one thing, and in the end another. So, I guess in this period, the understanding was greater. (Arthur, interview).

Oh, I think it's because we still love each other, we have our small fights occasionally, but we love each other. He's all about companionship, we are always together, when we are in the countryside, if one is going out shopping, then both go. (Liz, interview). I think it's this partnership, the coexistence of respect. (Claire, interview).

I think it's understanding. The most correct word is understanding between us two, we do not argue, we do not keep complaining. (Paul, interview). 
I think it is God, our religion, we have been participating in various movements, religious groups, lectures, pastoralists... Besides God, friendship and love, the partnership. (Edson, interview).

To speak frankly, I think we still love each other. (Mary, interview).

In the participant Arthur's opinion, the coexistence with his wife Liz has worked through love and understanding over the years. He refers to the stages lived by the couple when he exposes that at the beginning the marriage there was one way, and then it went through changes. His speech expresses a beginning, a middle and an end, and this process is tied to youth, adulthood and elderly years. In this last stage, love is configured differently, it is not lost as he said, but has the connotation of companionship. Liz, Arthur's wife, also reveals that the feeling of love still exists even if there are any arguments. The partnership for this couple is an important element.

According to Rios (2008), facing the current hedonistic society in the West, the reward for sustaining a relationship over the years may seem neglectable, since uninterrupted pleasure is the motto of amorous links. The gain is not immediately perceived and does not boil down to the junction of the moments of ecstasy, for the real gain would rely on the changes that occurred in the subjects from their experiences of intersubjectivity. This way, marriages that overcome the various transformations during the life cycle may have marital satisfaction factors and elements that keep the spouses together.

Partnership and understanding appear as fundamental pieces in other lines. For Claire and Paul, understanding promotes a sense of welcoming, empathy and appreciation. Thus, marriage satisfaction is closely linked to mutual acceptance. Moreover, the one who manages to express emotions and feelings in a healthy way contributes to the well-being of their pair, being the reason why the empathy that unfolds in marital dynamics from the understanding is of paramount importance to the family system balance (Sardinha, Falcone, \& Ferreira, 2009).

Edson (Kelly's husband) confirms that the belief in God was an element of change and maintenance to their union. From the moment they've decided to engage in the church works and to shape their relationship with spirituality, he believes, for the most part, that God is responsible for his marriage stability. In this sense, religiosity plays a protecting role for the couple. In line with Alves-Silva et al. (2017), religiosity can be considered as a strategy to confront marital crisis over time and can function as a maintainer of the relationship.

Mary synthesizes saying that regardless of how each couple built their story, love prevails, even if it is experienced differently in elder age and it assumes the facet of caring and companionship. Their love thus derives from a social construction and for this reason, its understanding encompasses variables that justify why love is understood in different ways by people. Regardless of how the couple perceives love, this feeling reaffirms the commitment to the relationship. Thus, the elderly tends to invest emotionally in the marriage, prolonging its durability as they seek to take care of their partner and of their shared life project.

The overall perception is that the maintenance of marriage depends on several factors, such as the affection demonstrations, partnership, fellowship, friendship, physical attraction, among others, after all each conjugality is unique and has different needs. Not every couple that has been together for years is necessarily satisfied: they may be only stable but the union, in some cases, be dysfunctional. This category analysis makes it clear that in the relationship the spouses have affective needs to be received and this reflects on how each elderly person copes with the life cycle transformations. 


\section{Final Considerations}

It is considered that the research reached its main objective which was to understand the marital dynamics of elderly couples married for more than 20 years. In the study, it was possible to realize that the conjugality is an area of interlocution between the "l" and the "we", that is, two individuals, who have their own characteristics, who when joined together inaugurate an identifying thread in the dynamics as two.

The results revealed that the participants were, in a contumacious way, wrapped up in the couples' parental models that they had experienced in their lives, both in seeking similarity, in relation to them, as in seeking differentiation. This influence is notorious both in understanding marriage and in why they chose their marital peers. The phenomena of psychic inheritance and the intergenerationality are evidenced that way. As for the experience of conjugality in elderly years, the partners revealed how much they had matured over the years, and that despite the changes in the life cycle, the affection of each other endured adversity.

In relation to the aspects that hold them together, the couples, for the most part, did not inform the same reasons why they chose to marry their partners, but instead, how love, today perceived as companionship and partnership, make them feel safe in the relationship. For them, in general, the lasting relationship is sustained with everyday complicity, guided by respect and trust. However, despite the average in married years being 41.6 years old, the answers related to the maintenance of the relationship were distinct, that is, each spouse perceives the marriage in a different way. It is believed that one of the main findings of this study was the presence of an individual perception of each spouse regarding the marriage, because it revealed that the amount of years together does not negate subjectivity, because each one of them remain united to the other by a personal factor that is linked to the history of the couple, but also to the family history.

This study has found its limits in certain issues such as the fact that the sample is homogeneous in relation to religion and culture. Regarding intergenerational patterns, the results could be further explored if the couple's children had also been interviewed, so the three-generation analysis would make it clearer how each family maintains the patterns of spouse choice. For this, the genogram would be an excellent family analysis tool. In addition, working the Family Life Cycle more closely would reveal what significant changes have occurred from the beginning of marriage to the moment of finitude they are in.

In this context, to better understand the conjugality in elder years, it is proposed that more studies can be carried out to help the health prevention and promotion for the elderly and to build up further knowledge in Psychology. After all, the study revealed that marriage can function as a protection factor for the elderly, since their years lived next to a person diminishes the loneliness feeling and the presence of psychopathologies. Also the widowhood can be set up as a traumatic event of difficult re-significance to those who spent more time of their lives beside their pairs than on their own.

\section{Funding}

The authors have no funding to report.

\section{Competing Interests}

The authors have declared that no competing interests exist. 


\section{Acknowledgments}

The authors have no support to report.

\section{References}

Almeida, E., \& Romagnoli, R. C. (2017). Assim como nossos pais? Conjugalidade: repetição, transformação e criatividade [As our parents before? Couple relationship: Repetition, transformation and creativity]. Psicologia Clínica, 29(2), 229-251.

Alves-Silva, J. D., Scorsolini-Comin, F., \& Santos, M. A. (2017). Bodas para uma vida: motivos para manter um casamento de longa duração [Entire life's wedding: Reasons to maintain a long-term marriage]. Temas em Psicologia, 25(2), 487-501. https://doi.org/10.9788/TP2017.2-05

Andolfi, M., Angelo, C., \& Saccu, C. (1990). La coppia in crisi [The crisis of the couple]. Rome, Italy: ITF.

Bardin, L. (2007). L'Analyse de Contenu [Content Analysis]. Paris, France: PUF.

Bauman, Z. (2015). Modernity liquid. Cambridge, United Kingdom: Polity Press.

Brasil. (2015, November 30). Em 10 anos, taxa de divórcios cresce mais de 160\% no País [In 10 years, divorce rate grows more than $160 \%$ in the Country]. Retrieved from http://www.brasil.gov.br/cidadania-e-justica/2015/11/em-10-anos-taxa-de-divorcios-cresce-mais-de-160-no-pais.

Carter, B. E., \& McGoldrick, M. E. (1995). The changing family life cycle: A framework for family therapy. New York, NY, USA: Gardner Press.

Dessen, M. A., \& Braz, M. P. (2000). Rede social de apoio durante transições familiares decorrentes do nascimento de filhos [Social support network during family transitions to parenthood]. Psicologia: Teoria e Pesquisa, 16(3), 221-231. https://doi.org/10.1590/S0102-37722000000300005

Eiguer, A. (2008). Jamais moi sans toi: Psychanalyse des liens intersubjectifs [Never me without you: Psychoanalysis of intersubjective links]. Paris, France: Dunod.

Féres-Carneiro, T., \& Ziviani, C. (2009). Conjugalidades contemporâneas: um estudo sobre os múltiplos arranjos conjugais na atualidade [Contemporary conjugalities: A Study of today's multiple love arrangements]. In T. Féres-Carneiro (Ed.), Casal e família: permanências e rupturas [Couple and family: Stays and breaks] (pp. 83-107). São Paulo, Brasil: Casa do Psicólogo.

Folstein, M. F., Folstein, S. E., \& McHugh, P. R. (1975). Mini-Mental State: A practical method for grading the cognitive state of patients for clinician. Journal of Psychiatric Research, 12(3), 189-198. https://doi.org/10.1016/0022-3956(75)90026-6

Fooken, I. (2015). A Formação na Maturidade como Apropriação da Própria História de Vida [Education in old age as appropriation of one's own life history]. Educação e Realidade, 40(1), 17-32. https://doi.org/10.1590/2175-623647790

Freud, S. (2001). On narcissism: An introduction. In The standard edition of the complete psychological works of Sigmund Freud. (Vol. 14, pp.73-102). London, United Kingdom: Hogarth Press (Original work published 1914). 
Giddens, A. (1992). The transformation of intimacy: Sexuality, love and eroticism in modern societies. Stanford, CA, USA: Stanford University Press.

Kaës, R. (2013). Le sujet de l'héritage. Introduction au concept de transmission psychique dans la pensée de Freud. In R. Kaës, H Faimberg, M. Enriquez, \& J.-J. Baranes (Eds.), Transmission de la vie psychique entre générations [Transmission of psychic life between generations] (pp. 1- 58). Paris, France: Dunod.

Minuchin, S., \& Fishman, H. C. (2004). Family therapy techniques. Cambridge, MA, USA: Harvard University Press.

Norgren, M. B. P., Souza, R. M., Kaslow, F., Hammerschmidt, H., \& Sharlin, S. A. (2004). Satisfação conjugal em casamentos de longa duração: uma construção possível [Marital satisfaction in long lasting marriages: A feasible construction]. Estudos de Psicologia, 9(3), 575-584. https://doi.org/10.1590/S1413-294X2004000300020

Pereira, D., Ponte, F., \& Costa, E. (2018). Preditores das atitudes negativas face ao envelhecimento e face à sexualidade na terceira idade [Predictors of negative attitudes towards aging and sexuality in the elderly]. Análise Psicológica, 36(1), 31-46. https://doi.org/10.14417/ap.1341

Puget, J., \& Berenstein, I. (1993). Psicoanalisis de la Pareja Matrimonial [Psychoanalysis of the marriage couple]. Buenos Aires, Argentina: Paidos.

Quissini, C., \& Coelho, L. R. M. (2014). A influência das famílias de origem nas relações conjugais [The influence of family values in marital relationships]. Pensando Famílias, 18(2), 34-47.

Rabelo, D. F., \& Neri, A. L. (2015). Tipos de configuração familiar e condições de saúde física e psicológica em idosos [Family configuration and physical and psychological health status in a sample of elderly]. Cadernos de Saude Publica, 31(4), 874-884. https://doi.org/10.1590/0102-311X00087514

Rios, I. (2008). O amor nos tempos de Narciso [Love in the time of Narcissus]. Interface: Comunicacao, Saude, Educacao, 12(25), 421-426. https://doi.org/10.1590/S1414-32832008000200016

Sardinha, A., Falcone, E. M. O., \& Ferreira, M. C. (2009). As relações entre a satisfação conjugal e as habilidades sociais percebidas no cônjuge [The relations between marital satisfaction and social skills perceived in the spouse]. Psicologia: Teoria e Pesquisa, 25(3), 395-402. https://doi.org/10.1590/S0102-37722009000300013

Strey, M. N., Matos, F. M. B., Medeiros, P. F., Cardoso, L. W., Mello, D. C., Stefani, M., \& Torres, S. B. (1999). Velhice e casamento, vivências e visões [Old age and marriage, living and visions]. Estudos Interdisciplinares sobre o Envelhecimento, 2, 23-34.

Wagner, A., \& Levandowski, D. (2008). Sentir-se bem em família: um desafio frente à diversidade [Feeling well in family: A challenge towards diversity]. Revista Textos \& Contextos, 7(1), 88-97. 